\title{
EXISTING STATUS AND PRACTICES OF FISH FARMING IN TRISHAL UPAZILA OF MYMENSINGH DISTRICT
}

\author{
S. Sheheli*, K. Fatema and S. M. Haque \\ Department of Agricultural Extension Education, Bangladesh Agricultural University \\ Mymensingh-2202, Bangladesh
}

\begin{abstract}
The study was conducted to investigate the existing status and practices of fish farming. A total of 100 farmers were interviewed by using a structured interview schedule from three villages (Porabari, Mathabari and Vabanipur) of Trishal upazila of Mymensingh district at their houses and/or farm sites during January to May 2013. Most of the farmers (89\%) made profit from fish production. The study confirmed that most farmers have improved their socio-economic conditions through fish production which plays an important role in increasing income, food production and employment opportunities. Five major areas are identified to improve the existing fish farming situation, which are quality fry, credit facilities, low-cost quality feed, training, and marketing channel. The impact analysis of fish farming on livelihood of fish farmers shows that overall $64 \%$ fish farmers have increased overall livelihood from fish farming during the last four years (20102013). Access to micro-credit, provide good quality input such as fry, feed, vaccines, etc., market facilities, supply of improve technologies, and provide training all lead to increased fish production. The constraints index (CI) analysis shows that overall $74 \%$ fish farmers faced medium constraints for fish farming. A total of nine (9) main constraints identified hindering their fish farming, and major constraints are high production cost, lack of technical knowledge and inadequate supply of good quality fry etc.
\end{abstract}

Key Words: Fish, Farmers, Livelihood, Bangladesh

\section{INTRODUCTION}

In spite of steps to reduce poverty over the last three decades, Bangladesh remains one of the world's poorest and least developed countries. Within the overall agro-based economy of the country, fish production is crucial for livelihoods, income, animal protein, employment opportunities, nutritional security and food supply. About 10\% of the population directly and indirectly depends on fisheries for their livelihood (DoF, 2011). Around 400,000 ha of fish ponds/ditches and more than 900,000 households are involved in aquaculture (ADB, 2010). Fisheries are currently one of the most important sub-sectors of the national economy accounting for 5\% of gross domestic product and $6 \%$ of export earnings. The total fish production in Bangladesh in 2006 was estimated at 2.32 million tons, of which 0.89 million tons (38\%) were obtained from inland aquaculture, 0.96 million tons $(41 \%)$ from inland capture fisheries and 0.48 million tons $(21 \%)$ from marine fisheries (DoF,

*Corresponding author (Email: ssheheli@yahoo.com) 
2007). In Bangladesh, around $46 \%$ of children between the ages 6 to 7 years are stunted and $70 \%$ are wasted due to malnutrition (Ahmed et al., 2007). The greater emphasis should be given to meet the animal protein deficiency among the people as well as to boost up fish production in this country through proper management of open water fishery and aquaculture. But fish production from open water bodies is decreasing day by day (DoF, 2012). Once upon a time, these unique ecosystems supported huge and diverse biodiversity. At present, most of the water bodies are contaminated by agricultural, industrial and municipal waste as a pollutant and those are accumulated by runoff into these resources. Aquatic organisms are silent victims of chlorine sub-lethal toxicity resulting from different types of pollutants (Bernet et al., 1997). Fish production is also decreasing due to natural causes like flood, drought, etc. (Chakraborty, 2009). But it is important that closed water or pond fishery production is increasing day by day due to necessitate and demand of the people (Ahmed, 2010). In addition more return also come from the fish production (DoF, 2012).

To fulfill the need of time, dependency on culture fisheries and pond aquaculture is increasing to a great extent, of which pond aquaculture is of greatest importance. With the increasing demand for fish and the decline in capture fish production, small indigenous species (SIS) farming in Bangladesh is becoming more intensive (Ahmed et al., 2007). A current focus is on promoting viable SIS farming with carp for local food supply and to increase the income of poor farmers. SIS can be integrated into existing carp culture without negative effects (Roos, 2001; Roos et al., 2003). For the improvement of cultural system and future planning, the information regarding present aquaculture practices at the grass root level is absolutely necessary. This study seeks to understand how fish farming lead to improve the status and practices of fish farming as well as improve their livelihood. Therefore, the present study is conducted with the following specific objectives:

i. to determine the existing status and practices of fish farming;

ii. to identify the existing constraints which hindering fish farming of the fish farmers; and

iii. to collect and formulate farmers' suggestions to conduct fish farming for improving their livelihood.

\section{MATERIALS AND METHODS}

The study was undertaken in Trishal Upazila of the Mymensingh district in north-central Bangladesh. Trishal was selected as it is an important area for fish farming due to the availability of fish fry, favorable resources and climatic conditions, such as the availability of ponds and low lying agricultural land, warm climate, fertile soil, and cheap and abundant labor. The maximum number of farmers made fish farming in Trishal. Data were collected for five months from January to May 2013. Questionnaire interviews with fish farmers were preceded by preparation and testing of the questionnaire, use of statistical procedures to determine the sample size and sampling method. A total of 100 farmers were interviewed from three villages (Porabari, Mathabari and Vabanipur) of Trishal Upazila at their houses and/or farm sites. The interviews, lasting about two hours, focused on fish 
production systems, productivity, impact of fish farming on their livelihood and constraints of fish farming etc. Cross-check interviews were conducted with District and Sub-district Fisheries Officers, researchers and relevant non-government organization (NGO) workers. Where information was found to be contradictory, further assessment was carried out. A total of 4 key informants were interviewed. Moreover, secondary information (web articles, organizations reports, and scientific reports) were used to crosscheck, complement or illustrate the primary data, collected through the survey schedule. Data from questionnaire interviews were coded and entered into a database system using Microsoft Excel software.

The identification and determination of the prevailing status and practices of fish farming is one of the main objectives of this study. The eleven selected dimensions were used to determine the existing status and practices of fish farming. These are: year of fish farm establishment and its' possession, experience of technical assistance and training, prestocking management, use of chemicals, cultured species and stocking density, feed for fish farming, occurrence of disease outbreak, harvesting and marketing of fish, yield from fish farming, annual income, savings and credit, and impact of fish farming on their livelihood. Nine potential constraints, related to economic, social and technical aspects were selected based on the results of the pre-test. Fish farmers were asked to indicate their response for each constraint on a four-point scale (Rahman et al., 2007) where 3 assigned for 'severe', 2 for 'significant', 1 for 'insignificant' and 0 for 'not at all'. As 9 constraints were considered, the possible score for constraint in fish farming of a fish farmer could vary from 0 to 27. Finally, a constraint index $(\mathrm{CI})$ was calculated for ranking the constraint as follows:

Constraint Index $(\mathrm{CI})=\mathrm{C}_{3} \times 3+\mathrm{C}_{2} \times 2+\mathrm{C}_{1} \times 1+\mathrm{C}_{0} \times 0$

Where, $C_{3}=$ frequency of fish farmer faced 'severe' constraints to conduct fish farming;

$\mathrm{C}_{2}=$ frequency of fish farmer faced 'significant' constraints to conduct fish farming;

$\mathrm{C}_{1}=$ frequency of fish farmer faced 'insignificant' constraints to conduct fish farming; and

$\mathrm{C}_{0}=$ frequency of fish farmer faced 'not at all' constraints to conduct fish farming.

Constraint index (CI) could range from 0 to 300 where ' 0 ' indicate lowest constraint and ' 300 ' indicate highest constraint faced by fish farmer to conduct fish farming.

\section{RESULTS AND DISCUSSION}

\section{Existing status and practices of fish farming according to the perception of fish farmer Year of fish farm establishment and its' possession}

A large number of small and marginal farmers are associated with fish farming in the study area. The data generated from the survey shows that $47 \%$ farmers established their farms between 2000 and 2004, where 30\% in or after 2005, 18\% between 1995 and 1999 and only $5 \%$ of farmers were between 1990 and 1994. Of the fish farmers, 70\% were established their fish farms on own land and 30\% were established on leased land. A general belief of the fish farmers $(89 \%)$ is that more profit come from it than crop agriculture. That is why; large number of cultivable lands is converted into fish farms. In the study area, the average pond size was $0.22 \mathrm{ha}$. The highest proportion ( $49 \%$ ) of the fish farmer belonged to the $0.37 \mathrm{ha}$, $22 \%$ to the 0.20 ha and $11 \%$ to the 0.11 ha. 


\section{Experience of technical assistance and training}

Fifty percent of farmers acquired fish farming experience from friends and neighbors where $33 \%$ received formal training from different organizations such as: DoF, BFRI and NGOs and remaining $17 \%$ have no fish farming experience. Data shows that they entered into fish farming by their self experience and still now they are continuing it. Result indicates that $50 \%$ farmers gain their knowledge from friends and neighbors. So, formal training is not frequent in the survey areas. It is important that $50 \%$ farmers were expecting training regarding fish farming.

\section{Pre-stocking management}

Preparation of pond is essential precondition to get more production from fish culture. Some steps were followed by the farmers before stocking fish. These are dike repairing, remove the excessive mud from the bottom of the pond; eradicate predatory and undesired fish, lime and fertilizer application, etc. In pre-stocking management, all farmers eradicate undesired weeds, predatory and undesired fish and repair their dike. Almost all (86\%) farmers dried their ponds when quality of water becomes deteriorated, among them $54 \%$ used lime @ 1kg/dec, while $46 \%$ used @ $1.5 \mathrm{~kg} / \mathrm{dec}$. In the study area, farmers used fertilizers mainly in the form of cow dung, urea and triple super phosphate (TSP) at various rates. The purpose of using fertilizers in the ponds was to increase the production of natural feeds (phytoplankton, zooplankton), thereby increasing fish production. It was also found that $86 \%$ farmers fertilized their pond by using cow dung (@ $150 \mathrm{~kg} / \mathrm{ha}$ ) before stocking. In the study area, the use of cow dung is widespread due to being relatively cheap and available.

\section{Use of chemicals}

Farmers used various chemicals and toxic substances like- lime, salt, $\mathrm{KMnO} 4$, dipterex, copper sulphate, methylene blue, malachite green, calcium hypochlorite and antibiotics in the study area. Of the fish farmers, $100 \%$ farmers used these chemicals and toxic substances, which are used to control aquatic weeds, pests, predators and undesirable species and prevent different fish diseases. It also appears that $22 \%$ farmers used antibiotics. Aoki (1992) reported that the use and sometime abuse of antibiotics in more intensive farming has led to multiple drug resistance among the pathogens. These chemicals and antibiotics may have lethal or sub lethal effects on non-target organisms in the environment. Pillay (1992) stated that there is a possibility of generating drug-resistant strains of pathogens by the use of antibiotics for treating diseases into the environment. As the resistance to antibiotic can be transmitted from one bacterium to another, there is a risk of transference of antibiotic resistance to normal bacteria in the human gut if antibiotic resistant bacteria are ingested in numbers. Boyd and Massout (1999) reported about the risks associated with the use of chemicals in pond aquaculture.

\section{Cultured species and stocking density}

In the study area, both exotic and indigenous species were cultured by fish farmers with similar emphasis and stocked indian major carp such as catla (Catla catla), rohu (Labeo rohita), mrigal (Cirrhinus cirrhosus), and exotic carp: silver carp (Hypophthalmichthys molitrix), 
grass carp (Ctenopharyngodon idella) and common carp (Cyprinus carpio). The average size of fingerlings was $5.56 \mathrm{~cm}$ in length and $12 \mathrm{gms}$ in weight. Farmers also produced SIS with carp in their ponds. The most common small indigenous species are: mola (Amblypharyngodon mola), puti (Puntius sophore), koi (Anabas testudineus), shing (Heteropneustes fossilis), magur (Clarias batrachus), etc. The average annual stocking density of SIS was 20,671 per ha. According to literature and fisheries specialist, average stocking density of fish is 17,370 fry / ha (Islam, 2005).

\section{Feed for fish farming}

A variety of feeds were used in fish production. Farmers mainly used three types of feed such as loose, pellet and both (loose + pellet). Among the farmers, $70 \%$ farmers used loose feed, $23 \%$ used both types and only $7 \%$ used pellet. Loose feed was prepared by the farmers with their own feed machine; while pellet was prepared by different fish feed companies. Usually farmers collect these pellets from the local market. Different hormones, antibiotics and growth promoter also used as feeds additives for fish culture. All of the farmers did not know the recommended doses of these supplementary components. The indiscriminate use of mediated feeds with hormones, antibiotics and growth promoter often caused disease outbreaks in hatcheries, nurseries and farms (Hossain et al., 2001). It is important that these chemicals also have harmful effects on human health. In the study area, $75 \%$ farmers applied feed twice in a day, while $20 \%$ of farmers applied thrice and only $5 \%$ applied feed once per day. The recommended feeding frequency is two or three times per day (DoF, 2009). Of the farmers, $68 \%$ said that the average annual feeding rate was 4583 $\mathrm{kg} /$ ha. Twenty two percent (22\%) farmer used $3827 \mathrm{~kg}$ feed/ha, while $10 \%$ farmer used $5103 \mathrm{~kg} / \mathrm{ha}$.

\section{Occurrence of disease outbreak}

Every farmer took preventive measure to keep away their ponds from disease outbreak. The common preventative measures found in the study area are pond drying, lime application, controlling weed, remove undesirable fish, change dirty water etc. In the study area some fish diseases were seasonal and some were found round the year caused by bacterial, viral or fungal infection. Seventy three percent (73\%) farmer reported that their cultured fish was occasionally attacked by diseases, while $12 \%$ fish farmers found disease outbreak every year. Fifteen percent $(15 \%)$ fish farmers did not found fish diseases in the pond. The most common diseases were tail and fin rot, epizootic ulcerative syndrome (EUS), unknown disease, oxygen deficiency disease, argulosis, saprolegniasis, gas bubble disease and nutritional deficiency.

\section{Harvesting and marketing of fish}

The pick period of fish harvesting was November to December. The farmers complete their harvesting after one year and partial harvest also done by some farmers from May to July. Most of the farmers (64\%) practiced total harvest and others (36\%) practiced partial harvest to get more benefit. Ahmed (2003) stated the peak harvesting season was from December to March. A large number of farmers (43\%) harvested their fish by the middlemen harvester team and 33\% farmers hired a local harvester team but $24 \%$ farmers harvested themselves. In the study area, farmers harvested their fish by using a cast net (Jhaki jal) and seine net or 
by total drying of pond. Data shows that $75 \%$ farmer harvested fish by using cast net and seine net and $25 \%$ farmers used other methods.

Table 1. Existing status and practices of fish farming considering eleven dimensions

\begin{tabular}{|c|c|}
\hline Dimensions & Key findings \\
\hline $\begin{array}{l}\text { Year of fish farm } \\
\text { establishment and its' } \\
\text { possession }\end{array}$ & $\begin{array}{l}\text { - } 47 \% \text { farmers established their farms during } 2000-2004 \\
\text { - The average pond size was } 0.22 \text { ha } \\
\text { - Agricultural land especially paddy field has converted to } \\
\text { aquaculture }\end{array}$ \\
\hline $\begin{array}{l}\text { Experience of technical } \\
\text { assistance and training }\end{array}$ & $\begin{array}{l}\text { - } 33 \% \text { farmer received formal training from different organizations } \\
\text { - } 50 \% \text { farmers were expecting training }\end{array}$ \\
\hline Pre-stocking management & $\begin{array}{l}\text { - Farmers used fertilizers in their pond mainly in the form of cow } \\
\text { dung, urea and triple super phosphate } \\
\text { - } 86 \% \text { farmers fertilized their pond by using cow dung (@150 kg/ha) }\end{array}$ \\
\hline Use of chemicals & $\begin{array}{l}\text {-100\% farmers used chemicals and toxic substances to control } \\
\text { aquatic weeds, pests, predators and prevent different fish diseases }\end{array}$ \\
\hline $\begin{array}{l}\text { Cultured species and stocking } \\
\text { density }\end{array}$ & $\begin{array}{l}\text { - Both exotic and indigenous species were cultured } \\
\text { - The average annual stocking density of SIS was } 20,671 / \text { ha }\end{array}$ \\
\hline Feed for fish farming & $\begin{array}{l}\text { - } 75 \% \text { farmers applied feed twice in a day } \\
\text { - } 68 \% \text { said that the average annual feeding rate was } 4583 \mathrm{~kg} / \mathrm{ha}\end{array}$ \\
\hline $\begin{array}{l}\text { Occurrence of disease } \\
\text { outbreak }\end{array}$ & $\begin{array}{l}\text { - } 73 \% \text { farmer reported their cultured fish was occasionally attacked } \\
\text { by diseases }\end{array}$ \\
\hline $\begin{array}{l}\text { Harvesting and marketing of } \\
\text { fish }\end{array}$ & $\begin{array}{l}\text { - } 64 \% \text { practiced total harvest } \\
\bullet 75 \% \text { farmer harvested fish by using cast net and seine net } \\
\text { - } 82 \% \text { of harvested fish are sold to the wholesalers or local agents }\end{array}$ \\
\hline Yield from fish farming & - Fish production was $6,752 \mathrm{~kg} / \mathrm{ha}$ \\
\hline $\begin{array}{l}\text { Annual income, savings and } \\
\text { credit }\end{array}$ & $\begin{array}{l}\text { - The average annual income of fish farmer was Tk. } 228,300 \\
\text { - } 71 \% \text { farmer used their own money for fish farming } \\
\text { - The average amount of credit received by a farmer was Tk. } \\
\text { 8880/year from all sources }\end{array}$ \\
\hline $\begin{array}{l}\text { Impact of fish farming on } \\
\text { their livelihood }\end{array}$ & $\begin{array}{l}\text { - } 64 \% \text { farmer indicated that their livelihoods improved through fish } \\
\text { farming }\end{array}$ \\
\hline
\end{tabular}

Around $82 \%$ of harvested fish are sold to the wholesalers or local agents, which transported to the district markets in Mymensingh, 20-30 km from the study area. The rest (18\%) of the under-sized fish are sold to local markets in Trishal. The average prices of carp and SIS were Tk. 190 and Tk. $210 \mathrm{~kg}^{-1}$, respectively in district town. Fish prices depend on size, weight, quality, seasonality, supply and demand, and distance to markets. Heavy rains often destroy the muddy roads in villages making them eventually inaccessible for the rickshaws, vans and motorised vehicles to carry fish to the markets. This leads to high transport costs and hence low profit margins. In addition to these problems, farmers are in a particularly 
weak position in relation to intermediaries. A large number of rural poor including women and children operate in the fish marketing chain as intermediaries, day labourers and transporters. The market chain from farmers to consumers encompasses mainly primary, secondary and retail markets, involving local agents, suppliers, wholesalers and retailers. Plastic containers are commonly used for containing the fish during transport. Fish are traded whole, un-gutted and fresh without processing apart from sorting and icing.

\section{Yield from fish farm}

In the study area, fish production was 6,752 kg/ha, where Biswas (2003) reported that fish production was $3,743 \mathrm{~kg} / \mathrm{ha}$ in Mymensingh district. In addition, the average annual yield of carp and SIS were estimated at $3217 \mathrm{~kg} / \mathrm{ha}$ and $929 \mathrm{~kg} / \mathrm{ha}$, respectively. Kamruzzaman (2011) estimated average annual yield of carp production is $2,925 \mathrm{~kg} / \mathrm{ha}$ in Bhaluka. It is significant that the fish production is high in the study area because of soil fertility, environment, lower water pollution, proper management by the farmer and farmers' own interest on fish farming.

\section{Annual income, savings and credit}

The lowest annual income of fish farmer from one hectare area was Tk. 192,930 and the highest income was Tk. 348,650 per year with the mean Tk. 228,300. Based on annual income, the fish farmer were classified into three categories namely 'low income' ( $\leq$ Tk. 200 thousand), 'medium income' (Tk. 201-300 thousand), and 'high income' (Tk. >300 thousand). With regard to total income, a high variability was observed, where the majority of fish farmer $(85 \%)$ fell under low to medium income categories and very few had a high income $(15 \%)$. The causes for the low per capita income mentioned by fish farmer are: many household members, loss of farm income, insignificant earning, and chronic illness of the main earners. In addition, six items were identified as the important reason behind the low to medium income of fish farmers: spent most of their incomes on basic items like food, housing, clothing, medication, and marriage of their sons and daughters, dowry payments, etc. In the study area, the savings performance of fish farmer was calculated based on both informal and formal saving mechanisms. The overall savings in the study area were very small. Although most of the respondents (71\%) used their own money for fish farming, $29 \%$ received loans from NGOs, moneylenders and banks. However, due to lack of education farmers often go to moneylenders and pay high interest rates of $10 \%$ monthly (i.e. $120 \%$ yearly). The average amount of credit received by a farmer was estimated at Tk. 8880 per year from all sources.

\section{Opinion of fish farmers regarding impact of fish farming on their livelihood}

Fish farmer were asked whether there had been any changed aspect of their lives since performing fish farming over the last four years. Seven items of livelihood were selected as the major areas that changed by the increase in income and opinion of fish farmers are summarized in Table 2.

The majority of the fish farmer (64\%) indicated that their livelihoods improved through fish farming. The position in the family, water facilities, freedom in cash expenditure, and participation in social activities also increased remarkably. Many farmers (29\%) reported 
that involvement with fish farming does not change their livelihood status and 7\% mentioned that their livelihood status in fact was decreased. Loss of property due to discontinuation of income projects, unstable market prices, defaulting and the burden of loans were major reasons for the negative effects reported by fish farmer.

Table 2. Overall impact of fish farming on livelihood of fish farmer $(n=100)$

\begin{tabular}{l|c|c|c}
\hline \multirow{2}{*}{\multicolumn{1}{c}{ Statement }} & \multicolumn{3}{c}{ Opinion of fish farmer (\%) } \\
\cline { 2 - 4 } & Improved & Same as before & Decreased \\
\hline Household income & 61 & 35 & 4 \\
Position in the family & 85 & 20 & 5 \\
Housing condition & 55 & 45 & 0 \\
Health situation & 35 & 56 & 9 \\
Water facilities & 78 & 22 & 0 \\
Participation in social activities & 70 & 20 & 10 \\
Freedom in cash expenditure & 74 & 21 & 5 \\
Overall livelihood & 64 & 29 & 7 \\
\hline
\end{tabular}

\section{Problems faced by fish farmers towards fish farming}

The interviewed fish farmers faced a variety of multi-dimensional difficulties and constraints (economic, social and technical) that affected the fish farming activities as well as their livelihood. The view of fish farmers has here been ranked according to their index values. The constraint index (CI) of the 9 pre-selected constraints ranged from 179 to 274 . The most common constraint confronted by fish farmer is 'high production cost' $(\mathrm{CI}=274)$. Costs of fish farming were reported to have increased significantly in recent years as a result of increased costs of seed, feed, fertilizers and wage rates. Inadequate and costly finance can, therefore, be a major constraint to expand the fish farming. Naser (2009) identified the similar problems of pond fish culture in Bangladesh.

The second most important constraint was 'lack of technical knowledge'. Fish farmers indicated that they have less formal training in technical matters regarding fish farming, which keeps them away from using technology and up-to-date information. 'Inadequate supply of good quality fry' was the $3^{\text {rd }}$ most commonly encountered problem for the fish farmers. According to the report of fish farmers, the increase in fish hatchery and demand for fry decreased the quality of fry over time. Furthermore, poor infrastructure facilities such as earthen roads and lack of bridges created a marketing problem, and there was a lack of marketing channels. During monsoon, they faced difficulties to travel on the muddy roads. Often, they could not reach market sites easily and in a timely manner. Fish farmer also reported that poor health status was a barrier to conducting fish farming. They often suffered from diarrhea, cholera, dysentery, skin diseases, malnutrition, night blindness, and mosquito-borne diseases such as dengue fever and malaria. In addition, they reported that social insecurity and natural calamities hindered their fish farming. Fish farmers did not have enough leaflets, booklets and other information materials on fish farming. Therefore, 
supply of adequate finance though credit program, establishing good quality hatcheries to supply adequate fry on time, extension of technical knowledge by training program, selecting appropriate site for fish farming, taking appropriate preventive and controlling measures and extension of different facilities in the study area are essential.

\section{Overall constraints of fish farmer}

The observed constraint score ranged from 8 to 24 against a possible range score of 0 to 27 . From these constraint scores, fish farmers have been classified into three categories, namely low constraints $(\leq 8)$, medium constraints (9-16) and high constraints $(>16)$. Survey data shows that $74 \%$ of fish farmers faced medium constraints to conduct fish farming, while $21 \%$ faced high and $5 \%$ faced low constraints.

\section{Suggestions of fish farmers}

Suggestions by fish farmers to improve their livelihood status

Fish farmers suggested five major areas in order to improve livelihood situations. It is noteworthy that adequate supply of quality fry on time was most important to the fish farmers for improving their livelihood. In addition, they gave priority to credit facilities, low-cost quality feed, training, and marketing channel to improve their existing livelihood status.

\section{Suggestions of fish farmers to overcome barriers of fish cultivation}

Participants were asked to give their opinion on possible solutions to overcome barriers that hindered the fish cultivation. In response to financial, social and technical barriers, they suggested a number of initiatives that might be taken by development organizations (such as GOs, NGOs, and private organizations) to remove barriers and to improve fish cultivation. After a lively discussion with each other, they put forward the following suggestions which have been arranged in Table 3. Here, lower rank indicates the need first priority and higher rank indicate least priority to overcome the constraints.

Table 3. Possible solutions to overcome the constraints of fish farming as perceived by fish farmer $(\mathrm{n}=100)$

\begin{tabular}{l|c|c}
\hline \multicolumn{1}{c|}{ Solutions } & $\begin{array}{c}\text { Percent of } \\
\text { citations }\end{array}$ & Rank order \\
\hline Providing sufficient credit at low interest rate in time & 75 & 1 \\
Adequate supply of inputs (fry, fertilizer, hormone, vaccine) in time & 68 & 2 \\
Developing a cooperative society to resolve the marketing problems & 60 & 3 \\
$\begin{array}{l}\text { Providing sufficient need-based training facilities on fish farming } \\
\text { from GOs and NGOs }\end{array}$ & 56 & 4 \\
Providing sufficient extension services from DAE, DLS, DOF, etc. & 48 & 6 \\
$\begin{array}{l}\text { Adequate supply of technologies and information by skilled } \\
\text { personnel }\end{array}$ & 38 & 7 \\
Providing sufficient government support & & 29 \\
\hline
\end{tabular}




\section{CONSCLUSION}

From the present investigation it is evident that Trishal Upazila is very rich with aquaculture resources. Most of the farmers $(89 \%)$ made profit from fish production. The annual income from fish farming is relatively sound as of fish an economic perspective. The study confirmed that most farmers have improved their socio-economic conditions through fish production which plays an important role in increasing income, food production and employment opportunities. Five major areas are identified essential to improve the existing fish farming situation, which are quality fry, credit facilities, low-cost quality feed, training, and marketing channel. The impact analysis of fish farming on livelihood of fish farmers shows that overall $64 \%$ fish farmers have increased overall livelihood from fish farming during the last four years (2010-2013). Access to micro-credit, provide good quality input such as fry, feed, vaccines, etc., market facilities, supply of improve technologies, and provide training all lead to increase fish production. It is important to mention that the above opportunities are usually less accessible to the "fish farmers" in the study area.

The constraints index (CI) analysis shows that about $74 \%$ fish farmers faced medium constraints for fish farming. A total of nine (9) main constraints identified hindering their fish farming, and major constraints are high production cost, lack of technical knowledge, inadequate supply of good quality fry, inadequate training facilities, lack of marketing channels, poor transport facilities etc. Input services also need strengthening. In addition, the development of low-cost quality feed is essential to improve farmers' profit margins. The provision of low-interest credit would help to reduce the risks for small and marginal farmers. Farmers require credit at low interest rates from the government and national banks. Better training and extension services would also help to improve profitability and reduce risks. Farmer training and extension activities are relatively low cost methods of increasing production efficiency $(\mathrm{ADB}, 2005)$. It is, therefore, necessary to provide institutional, organizational and government support for sustainable fish farming in the study area.

\section{REFERENCES}

ADB. 2005. An evaluation of small-scale freshwater rural aquaculture development for poverty reduction. Asian Development Bank (ADB), Manila, Philippines.

ADB. 2010. An evaluation of small-scale freshwater rural aquaculture development for poverty reduction. Asian Development Bank (ADB), Manila, Philippines.

Ahmed, F. 2003. Comparative study on carp poly culture practices of three different NGOs in Mymensingh district, M. S. Thesis. Department of Fisheries Management, Bangladesh Agricultural University, Mymensingh.

Ahmed, N., Wahab, M. A., and Thilsted, S. H. 2007. Integrated aquaculture-agriculture systems in Bangladesh: Potential for sustainable livelihoods and nutritional security of the rural poor. Aquaculture Asia. 12(1): 14-22.

Ahmed, J. 2010. Attitude of farmers towards the effect of pond ownership on fish production. M. S. Thesis. Department of Agricultural Extension, Bangladesh Agricultural University, Mymensingh. 
Aoki, T. 1992. Chemotherapy and resistance in fish farms in Japan. In: Diseases in Asian Aquaculture, Asian Fisheries Society, Manila, 1 519-529.

Bernet, D. H., Schmidt, W., Meier, P., Burkhardt, H. and Wahli, T. 1997. Histopathology in fish, Proposal for a protocol to assess aquatic pollutions, J. Fish Dts., 22(1): 25-34.

Biswas, D. 2003. Study of the impacts of Aquaculture in and around fish farms in Mymensingh district. Progressive Agriculture, 11(1-2): 243-249.

Boyd, C. E. and Massout, L. 1999. Risks associated with the use of chemicals in ponds aquaculture, Aquacult Engg., 20(2): 113-132.

Chakraborty, B. K. 2009. Aquatic biodiversity of Someswari and Nethai River and Gharia and Nidaya Beel of Northern Bangladesh. In Takumi K. Nakamura (Ed.). Aquaculture Research Progress, Nova Science, Publishers, New York, USA. 3231-3268.

DoF. 2007. Fishery Statistical Yearbook of Bangladesh 2005-2006. Fisheries Resources Survey System, Department of Fisheries, Dhaka, Bangladesh.

DoF. 2009. Department of Fisheries, Ministry of Fisheries and Livestock, Jatiyo Matshya Saptaho, 54-56.

DoF. 2011. Fishery Statistical Yearbook of Bangladesh. Fisheries Resources Survey System, Department of Fisheries, Dhaka, Bangladesh.

DoF. 2012. Fishery Statistical Yearbook of Bangladesh. Fisheries Resources Survey System, Department of Fisheries, Dhaka, Bangladesh.

Hossain, M. A., Ahmed, M. and Islam, M. N. 2001. Mixed culture of fishes in seasonal ponds through fertilization and feeding. Bangladesh Journal of Fisheries Research, 1(2): 9-18.

Islam, M. S. 2005. Socio-economic status of fish farming in some selected areas of Dinajpur District. MS Thesis, Department of Fisheries Management, Bangladesh Agricultural University, Mymensingh.

Kamruzzaman, M. 2011. Study of aquaculture practices of Bhaluka Upazil, Mymensingh. M. S. Thesis, Department of Fisheries Management, Bangladesh Agricultural University, Mymensingh.

Nesar, A. 2009. The sustainable livelihoods approach to the development of fish farming in rural Bangladesh. Journal of International Farm Management, 4(4): 1-18.

Pillay, T. V. R. 1992. Aquaculture and the environment. Fishing News Book, Blackwell Scientific Publications Ltd., Osney mean. Oxford OX2 OEL., England, 189 pp.

RAHMAN, Z. M., Yamao, M. and Alam, M. A. 2007. Barriers Faced by Small Farmers in Adopting the Integrated Plant Nutrient System for Sustainable Farming Development. Sabaragamuwa University Journal, 7(1): $7 \mathrm{p}$.

Roos, N. 2001. Fish consumption and aquaculture in rural Bangladesh: nutritional contribution and production potential of culturing small indigenous fish species. Ph.D. Dissertation, The Royal Veterinary and Agricultural University, Department of Human Nutrition, Frederiksberg, Denmark.

Roos, N., Islam, M. M. and Thilsted, S. H. 2003. Small fish is an important dietary source of vitamin A and calcium in rural Bangladesh. International J. Food Science Nutrition, 54: 329-339. 